\title{
Retail Fees of Depository Institutions, 1997-2001
}

Timothy H. Hannan, of the Board's Division of Research and Statistics, prepared this article. Eli Mou provided research assistance.

With passage of the Financial Institutions Reform, Recovery, and Enforcement A'ct in 1989, the Congress directed the Board to report annually on changes in the availability of retail banking services and in the level of the associated fees. The first survey on retail fees and services commissioned by the Board under the new law was conducted in 1989 , and the results were reported in 1990. The most recent report, covering 2001, was released in June 2002.

Each year the reports present estimates of the proportion of all depository institutions that offer various services, the proportion that charge a fee for these services, the average level of the fees, and the changes in these estimates from the previous year. Statistical analysis of the survey results produces estimates for the entire population of commercial banks (hereafter referred to as banks) and savings associations in the United States. Selected estimates for each of the years from 1997 through 2001 are presented in this article. ${ }^{1}$

Starting with the report covering fees in 2000, estimates of the incidence and levels of fees for banks and savings associations have been combined. This change was made because the similarities between banks and savings associations have increased and, most particularly, because the deposit insurance premiums paid by the two types of institution have become virtually the same. To compare estimates across years in this article, estimates of fees previously reported separately for banks and savings associations were recalculated to apply to banks and savings associations together. ${ }^{2}$

1. For an examination of the results for 1989-93 survey years, see Timothy H. Hannan, "Recent Trends in Retail Fees and Services of Depository Institutions," Federal Reserve Bulletin, vol. 80 (September 1994), pp. 771-81, and for the 1994-99 survey years, see Timothy H. Hannan, "Retail Fees of Depository Institutions, 199499," Federal Reserve Bulletin, vol. 87 (January 2001), pp. 1-11. The reports covering the years $1996-2001$ are available at http:// www.federalreserve.gov/boarddoes/RptCongress/

2. Other differences may also be reflected in estimates reported for earlier years. In particular, the size categories of institution used to calculate sampling weights for the 1997 and 1998 data were altered to
Because of the interest expressed over the years in the question of whether retail fees differ by size of institution, this article also examines the differences in the incidence and levels of fees charged by institutions of different sizes.

Several findings for the 1997-2001 period are noteworthy: ${ }^{3}$

- For the various types of checking and savings accounts tracked, monthly fees tended to rise by statistically significant amounts, as did the minimum balances that depositors must maintain to avoid the fees.

- Fees associated with special actions, such as those imposed on checks returned for insufficient funds, on overdrafts, and on stop-payment orders, exhibited increases that were statistically significant and well in excess of the rate of inflation during the period.

- In the case of fees imposed for the use of automated teller machines (ATMs), the annual fee and the fee imposed for withdrawals by an institution's depositors from the institution's own ATMs, both of which were fairly rare in 1997, became even less common by 2001. However, the more commonly imposed fees for withdrawals by an institution's depositors from other institutions' ATMs and for the use of the institution's ATMs by nondepositors (the so-called surcharge) became much more common by the end of the period, and the average levels of these fees increased by statistically significant amounts; for the surcharge, this increase substantially exceeded the inflation rate during the period.

- Comparisons of the fees charged by institutions of different sizes in 2001 (the year of the latest survey) indicate that, in general, the incidence and levels of fees were higher at larger institutions.

conform with those categories used in later years. See the appendix for a detailed discussion.

3 . Here and in the annual reports, statistical significance is represented with 90 percent and 95 percent confidence levels. With a 95 percent confidence level, for instance, the probability is less than 5 percent that an observed change between two samples did not occur in the population as a whole. The finding of a statistically significant change carries no implication about the size of the change. The discussion in this article covers the statistically significant results, referring to them as such or simply as "significant." Only a few of the nonsignificant changes presented in the tables are discussed. 


\section{Background}

In 1989 , the Congress established assessment rules that were likely to increase the premiums that depository institutions paid for deposit insurance. This probable result raised a concern that institutions might offset their higher premiums by markedly increasing retail fees or eliminating some services. To address this concern, the Congress, in section 1002 of the Financial Institutions Reform, Recovery, and Enforcement Act of 1989 , directed the Board to report annually on changes in the availability of retail banking services and in the level of the associated fees. Section 1002 further specified that the reports be based on annual surveys of samples of insured depository institutions that are representative of all such institutions in terms of size and location.

The sampled institutions were members either of the Bank Insurance Fund, a group consisting mostly of commercial banks, or of the Savings Association Insurance Fund, a group consisting mostly of savings and loan associations. For all the surveys, the institutions were picked randomly from different regions of the country encompassing all fifty states and the District of Columbia and from a comprehensive range of asset-size groupings (see the appendix for more detail on the design of the sample). All the surveys were conducted by telephone with the same procedures and by the same private survey organization operating under contract with the Federal Reserve Board. To improve the accuracy of the results, each telephone interview typically covered only one product category.

Legislation in 1994 and 1996 required that trends be reported in more detail. Section 108 of the Riegle-Neal Interstate Banking and Branching Efficiency Act of 1994 required that data be reported not only nationally but also by geographic region and size class of institution and according to whether institutions engaged in multistate activities. Under section 2608 of the Economic Growth and Regulatory Paperwork Reduction Act of 1996, the geographic detail in the annual reports was increased from regional coverage to coverage for each state and each consolidated metropolitan statistical area. The first survey under these expanded terms was conducted in 1996.

\section{THE INCIDENCE AND LEVEL OF FEES OIER TIME}

Because of the wide variations in the fees charged by depository institutions for various services, fees are divided into three types in the following discussion to provide a manageable way of examining the variations. These types are fees associated with (1) maintenance and use of various kinds of deposit accounts, (2) special actions such as stop-payment orders and checks returned for insufficient funds, and (3) use of ATM services.

\section{Deposit Accounts}

Analysis of the fees charged in connection with deposit accounts must, at the very least, account for the distinctions among noninterest checking accounts, NOW (negotiable order of withdrawal) accounts, and savings accounts. Even within these categories, however, accounts may have different characteristics. For example, noninterest checking accounts can differ in terms of the nonchecking services provided, the minimum balances that depositors must maintain to qualify for various fee levels, and the mix of fees charged. Fees for savings accounts, to take another example, can depend on whether the account is a passbook savings account or a statement savings account and on minimum balance requirements. Therefore, the characteristics of accounts must be specified when comparing the levels of fees over time. The following discussion presents information on two types of noninterest checking accounts, one type of NOW account, and two types of savings accounts. Data on the proportion of institutions offering each of these accounts is included to indicate their prevalence.

Financial institutions offer many other types of noninterest checking accounts not analyzed in this article, including the so-called basic banking account. Basic banking accounts impose low fees and minimum balances (or none at all), often in exchange for limitations in service, such as a cap on the number of checks that may be written per month. Although the surveys do not provide direct evidence on the extent to which such accounts are offered, they do cover certain no-fee accounts. In 2001, about a third of banks and savings associations offered no-fee noninterest checking accounts, which entail no monthly or per-check fees. ${ }^{+}$

\section{Noninterest Checking}

The following two fee structures are reported for noninterest checking accounts: "single balance and fee" and "fee only" (table 1).

Single balance and fee. Single balance and fee accounts involve no fee if a specified minimum bal-

4. Board of Governors of the Federal Reserve System, Anmal Report to the Congress on Retail Fees and Services of Depository Institutions (Board of Governors, 2002), p.3, table 1. 
1. Selected checkable accounts at banks and savings associations, average low-balance fees and balance requirements, 1997-2001

Dollars except as noted

\begin{tabular}{|c|c|c|c|c|c|c|}
\hline Account & 1997 & 1998 & 1999 & 2000 & 2001 & $\begin{array}{c}\text { Percent } \\
\text { change, } \\
1997-2001\end{array}$ \\
\hline \multicolumn{7}{|l|}{ Noninterest checking } \\
\hline \multicolumn{7}{|l|}{ Single balance and fee ${ }^{1}$} \\
\hline Percentage offering....$\ldots \ldots$ & 31.9 & 30.2 & 37.2 & 38.1 & 29.6 & $\dagger$ \\
\hline Monthly low-balance fee ...... & 6.31 & 6.38 & 6.17 & 7.17 & 7.12 & $12.8 * *$ \\
\hline \multicolumn{7}{|l|}{ Minimum balance } \\
\hline To avoid fee & 467.37 & 464.52 & 517.72 & 486.21 & 526.58 & $12.7 *$ \\
\hline To open $\ldots$ & 124.58 & 113.58 & 109.05 & 154.51 & 116.06 & -6.8 \\
\hline \multicolumn{7}{|l|}{ Fee only ${ }^{2}$} \\
\hline Percentage offering & 29.1 & 31.4 & 37.3 & 41.0 & 37.7 & tok \\
\hline Monthly fee ............. & 4.69 & 4.81 & 4.95 & 5.12 & 4.74 & 1.1 \\
\hline Minimum balance to open & 65.80 & 88.51 & 60.98 & 63.17 & 71.31 & 8.4 \\
\hline \multicolumn{7}{|l|}{ NOW account } \\
\hline \multicolumn{7}{|l|}{ Single balance and fee } \\
\hline Percentage offering . . . . . . & 55.3 & 51.6 & 51.9 & 47.5 & 49.5 & $\dagger$ \\
\hline Monthly low-balance fee .......... & 7.50 & 7.61 & 8.24 & 8.60 & 8.15 & $8.7 * *$ \\
\hline \multicolumn{7}{|l|}{ Minimum balance } \\
\hline To avoid fee ... & 877.28 & 932.09 & $1,014.23$ & $1,044.76$ & $1,132.10$ & 29.0 ** \\
\hline To open $\ldots \ldots \ldots \ldots$ & 477.93 & 491.57 & 587.23 & 538.07 & 560.11 & $17.2 *$ \\
\hline
\end{tabular}

NotE. The change in the consumer price index between the dates of the 1997 and 2001 surveys was about 11 percent. Average fees and balance requirements are calculated only for those institutions that offer the account. Monthly lowbalance fees are the average fees charged account holders who fail to maintain the minimum balance.

$\uparrow$ Percent change for "percentage offering" not reported, but instances of statistically significant change are noted

* Significant at the 90 percent confidence level. For explanation of confidence levels, see text note 3

** Significant at the 95 percent confidence level.

1. A monthly fee for balances below the minimum, no monthly fee for balances above the minimum, and no other charges.

2. A monthly fee, no minimum balance to eliminate the fee, and a charge per check in some cases.

ance is maintained; otherwise the account incurs a single monthly fee with no other charges. The estimated proportion of banks and savings associations offering this account fluctuated between about 30 percent and 40 percent over the 1997-2001 period. The estimated average fee charged account holders who did not maintain the minimum balance (the "low-balance" fee) increased a statistically significant amount, from $\$ 6.31$ in 1997 to $\$ 7.12$ in 2001. This 12.8 percent increase was slightly higher than the approximately 11 percent increase registered by the consumer price index (CPI) between the dates of the 1997 and 2001 surveys. ${ }^{5}$ The minimum balance required to avoid the fee also increased a statistically significant 12.7 percent during the period, also exceeding by a small amount the rate of inflation. The average minimum balance required to open the account, however, did not change significantly during the period.

Fee only. Fee-only noninterest checking accounts levy a monthly fee regardless of the account balance and may also impose a per-check charge. Because of the small number of sampled institutions that levied a per-check charge for this type of account, information on the incidence and level of the check charge is

5. The CPI used throughout is the urban index, all items. Comparisons with the CPI are intended to indicate how fees and minimum balances changed in relation to changes in the prices of other common consumer items. not presented. The proportion of banks and savings associations offering this type of account increased significantly, from 29 percent in 1997 to about 38 percent in 2001. Neither the monthly fee nor the minimum balance required to open the account, however, changed by a statistically significant amount during the period.

\section{NOW Accounts}

NOW accounts are checking accounts that pay interest to the account holder. Presumably because NOW accounts pay interest, they have tended to have fees that are higher than those observed for noninterest checking accounts. Like noninterest accounts, they can differ considerably in terms of the balances that depositors must maintain to qualify for various fee levels and in terms of the mix of fees charged the account holder. A common type of fee structure associated with NOW accounts at banks and at savings associations involves no fee if the account holder maintains a minimum balance; otherwise, the institution assesses one monthly fee with no per-check charge.

The estimated proportion of banks and savings associations offering NOW accounts with this fee structure ranged from about 47 percent to 55 percent over the period (table 1). For this account, the average monthly fee charged account holders who failed 
to maintain the required minimum balance increased from $\$ 7.50$ in 1997 to $\$ 8.15$ in 2001 , a significant change of 8.7 percent, which is somewhat smaller than the 11 percent increase in the CPI over the same period. Also, the average minimum balance required to avoid this fee increased by a significant 29 percent, to $\$ 1,132$ in 2001 , while the average minimum balance required to open the account increased by a significant 17.2 percent, to $\$ 560$ in 2001 . Both these changes in required balances substantially exceeded the increase in the CPI over the period.

\section{Savings Accounts}

The two major types of savings accounts are the passbook account and the statement savings account. In passbook accounts, transactions and balances are recorded in a passbook kept by the account holder; in statement accounts, periodic statements of balances and recent activity are mailed to account holders. The most common fee structure imposes a monthly fee for balances below a specified minimum and no fee or other charge if the balance is above the minimum.

Over the 1997-2001 period, the proportion of banks and savings associations offering passbook accounts with this fee structure declined significantly, from about 34 percent in 1997 to 19 percent in 2001, while the proportion offering statement accounts with this fee structure increased significantly from about 40 percent in 1997 to 67 percent in 2001 (table 2). Thus, to a substantial degree, statement accounts with this common fee structure appear to be replacing the equivalent passbook account. For the passbook account, the average low-balance fee increased a statistically significant 16.2 percent, to $\$ 2.15$ in 2001 , but the increase registered for the statement account is not statistically significant. The minimum balance to avoid this fee for passbook accounts also increased a significant 21.6 percent during the period; however, the minimum balance did not increase for statement accounts. No significant changes were registered for the minimum balances required to open these accounts.

\section{Summary of Changes in Deposit Account Fees}

Among the three types of checkable accounts examined, the monthly fee increased significantly in two cases, and by a percentage that exceeded the increase in the CPI in one case. The average minimum balances required to avoid the monthly fees increased significantly for the two types of account for which it is relevant, in both cases by amounts that exceeded the increase in the CPI during the same period. The changes in the minimum balance required to open these accounts presented a more mixed picture, increasing significantly in only one case.

In the case of savings accounts, passbook accounts were less commonly offered by the end of the period, while statement accounts had become more common. For the passbook account, both the monthly lowbalance fee and the minimum balance required to avoid the fee increased significantly and by percentages that exceeded the increase in the CPI during the period. This was not the case, however, for statement accounts. The minimum balance required to open an account did not change by significant amounts for either type.

2. Selected "single balance and fee" savings accounts at banks and savings associations, average low-balance fees and balance requirements 1 $_{3}$ 1997-2001

Dollars except as noted

\begin{tabular}{|c|c|c|c|c|c|c|}
\hline Account & 1997 & 1998 & 1999 & 2000 & 2001 & $\begin{array}{c}\text { Percent } \\
\text { change, } \\
\text { 1997-2001 }\end{array}$ \\
\hline \multicolumn{7}{|l|}{ Passbook $^{1}$} \\
\hline Percentage offering .... & 33.8 & 34.2 & 29.7 & $\ldots$ & 19.1 & †** \\
\hline Monthly low-balance fee & 1.85 & 2.14 & 1.95 & $\ldots$ & 2.15 & $16.2^{*}$ \\
\hline \multicolumn{7}{|l|}{ Minimum balance } \\
\hline To avoid fee & 129.78 & 151.06 & 148.89 & $\ldots$ & 157.86 & $21.6^{*}$ \\
\hline To open $\ldots$ & 85.02 & 102.64 & 85.45 & $\ldots$ & 96.89 & 14.0 \\
\hline \multicolumn{7}{|l|}{ Statement $^{2}$} \\
\hline Percentage offering .... & 40.5 & 44.7 & 48.7 & $\ldots$ & 67.1 & $\dagger * *$ \\
\hline Monthly low-balance fee & 2.30 & 2.29 & 2.38 & $\ldots$ & 2.50 & 8.7 \\
\hline \multicolumn{7}{|l|}{ Minimum balance } \\
\hline To avoid fee... & 187.29 & 203.78 & 189.87 & $\ldots$ & 184.42 & -1.5 \\
\hline To open $\quad \ldots \ldots \ldots \ldots$ & 121.85 & 131.73 & 101.54 & $\ldots$ & 105.37 & -13.5 \\
\hline
\end{tabular}

Note. See general note to table 1

Data are not sufficient to report or are not applicable across surveys.

1. Institution records transactions and balances in document kept by the account holder.

2. Institution mails to the account holder a periodic statement showing transactions and balances. 
In general, for a majority of the accounts examined, the monthly fees and the minimum balances to avoid the fees rose significantly, often by amounts that exceeded the increase in the CPI during the period. Observed changes in the average minimum balances to open these accounts exhibited a more mixed picture.

\section{Special Actions}

The evidence on fees associated with special actions is unambiguous. The average charge for each of the four types of special action covered by the surveys rose by statistically significant amounts between 1997 and 2001 and considerably faster than the change in the CPI (table 3).

\section{Stop-Payment Orders}

Throughout the period, virtually all banks and savings associations charged for a stop-payment order, which is a request by a customer that the institution not pay a particular check previously written by the customer. The average at banks and savings associations rose from about $\$ 14.50$ in 1997 to more than $\$ 18$ in 2001, a statistically significant increase of more than 25 percent.

\section{NSF Checks and Overdrafts}

A check drawn on an account with insufficient funds may or may not be honored by the paying institution. When not honored, it is called an NSF (not sufficient funds) check; when honored, it is called an overdraft and represents an extension of credit. Throughout the period, nearly all depository institutions charged for NSF checks and overdrafts, and the fees were generally $\$ 2$ to $\$ 3$ higher than for stop-payment orders. The average charge for NSF checks rose significantly, from about $\$ 17$ in 1997 to about $\$ 20.75$ in 2001, while the average fee charged for overdrafts increased from $\$ 16.50$ to about $\$ 20.50$ during the same period. These increases of more than 20 percent were substantially greater than the increase in the CPI during the same period.

\section{Deposit Items Returned}

When a customer deposits a check that is returned by the paying bank (because of insufficient funds, for example), the bank in which it was deposited may charge the customer a fee. The levying of such charges is controversial. Many have argued that it is not the depositor's fault that the check is drawn on insufficient funds and that charging the depositor in such cases is therefore unreasonable. Others argue that such fees may provide a useful incentive for depositors not to accept checks thought likely to be returned for insufficient funds and that depository institutions have a right to recover their costs in ways available to them.

Perhaps because of the controversy surrounding this fee, the proportion of banks and savings associations that levy it has been smaller than for the fees associated with stop-payment orders, NSF checks, and overdrafts. Both its incidence and level, however, rose significantly over the 1997-2001 period. The

3. Fees for selected special actions - incidence and average level at banks and savings associations, 1997-2001 Dollars except as noted

\begin{tabular}{|c|c|c|c|c|c|c|}
\hline Item & 1997 & 1998 & 1999 & 2000 & 2001 & $\begin{array}{c}\text { Percent } \\
\text { change, } \\
\text { 1997-2001 }\end{array}$ \\
\hline $\begin{array}{l}\text { Stop-payment orders } \\
\text { Percentage charging } \\
\text { Fee }\end{array}$ & $\begin{array}{l}99.7 \\
14.42\end{array}$ & $\begin{array}{l}99.8 \\
15.03\end{array}$ & $\begin{array}{l}99.8 \\
15.26\end{array}$ & $\begin{array}{l}99.0 \\
17.54\end{array}$ & $\begin{array}{l}99.2 \\
18.08\end{array}$ & $254^{\dagger}$ \\
\hline $\begin{array}{l}\text { NSF checks } \\
\text { Percentage charging } \\
\text { Fee ................. }\end{array}$ & $\begin{array}{c}100.0 \\
17.15\end{array}$ & $\begin{array}{c}100.0 \\
17.64\end{array}$ & $\begin{array}{l}99.9 \\
17.88\end{array}$ & $\begin{array}{c}100.0 \\
20.22\end{array}$ & $\begin{array}{c}100.0 \\
20.73\end{array}$ & $\begin{array}{c}{ }^{\prime} \\
20.9^{* * *}\end{array}$ \\
\hline $\begin{array}{l}\text { Overdrafts } \\
\text { Percentage charging } \\
\text { Fee ....................... }\end{array}$ & $\begin{array}{l}97.3 \\
16.51\end{array}$ & $\begin{array}{l}97.3 \\
17.22\end{array}$ & $\begin{array}{l}99.6 \\
17.66\end{array}$ & $\begin{array}{l}97.4 \\
19.78\end{array}$ & $\begin{array}{l}99.7 \\
20.42\end{array}$ & $23.7^{\top}$ \\
\hline $\begin{array}{l}\text { Deposit items returned } \\
\text { Percentage charging } \\
\text { Fee }\end{array}$ & $\begin{array}{l}56.8 \\
5.88\end{array}$ & $\begin{array}{c}65.7 \\
5.98\end{array}$ & $\begin{array}{c}60.5 \\
6.33\end{array}$ & $\begin{array}{l}72.2 \\
7.01\end{array}$ & $\begin{array}{c}74.1 \\
7.11\end{array}$ & $20.9 * *$ \\
\hline
\end{tabular}

NotE. NSF (not sufficient funds) checks are those written without sufficient funds in the account to cover them; they are not honored by the paying bank or savings association. Overdrafts are checks written without sufficient funds but are honored by the paying institution. See also general note to table 1.

†Percent change for "percentage offering" not reported, but instances ofi statistically significant change are noted.

* Significant at the 90 percent confidence level.

*k Significant at the 95 percent confidence level. 
proportion of institutions charging the fee increased by a significant 17 percentage points, from about 57 percent in 1997 to 74 percent in 2001. Of those institutions that levied a fee, the average charge was typically between a third and a half of the charge for NSF checks. The amount charged, however, did increase significantly over the period, from nearly $\$ 6$ in 1997 to more than $\$ 7$ in 2001. This 21 percent increase was substantially greater than the increase in the CPI during the period.

\section{ATM Services}

Many fees may be assessed for services rendered by automated teller machines (ATMs). A depository institution may levy an annual fee on depositors that use its ATMs as well as impose separate fees on both depositors and nondepositors for various types of ATM transactions. Fees that the institution levies on its own depositors for use of ATMs may differ depending on whether the transaction is a withdrawal, a deposit, or a balance inquiry; further, the fee may vary depending on whether the institution's depositor uses the institution's own ATM (an "on us" transaction) or another institution's ATM (an "on others" transaction).

In the more recent surveys, information was elicited only on the cash withdrawal, since this is by far the most common type of transaction conducted using ATMs. Beginning with the 1996 survey, information was obtained on the incidence and level of the "surcharge," which is the fee levied by ATM owners on users who do not maintain an account with the depository institution operating the machine.
Survey results indicate that a small minority of institutions charged their customers an annual fee for the use of ATM services during the 1997-2001 period (table 4). The incidence of the fee declined significantly over this period, from about 15 percent in 1997 to about 11 percent in 2001. Although the average annual fee, as calculated from the survey information, varied over the period, its level in 2001 of about $\$ 10$ was not significantly different from that registered for 1997 (about \$11).

Another type of ATM fee that appears to have become, if anything, less common over the years has been the "on us" transaction fee, or the fee that the institution charges its own depositors for use of its own ATMs. Never exceeding a small proportion of institutions, the incidence of the fee for on-us withdrawals declined significantly, from more than 7 percent in 1997 to a mere 3.6 percent in 2001. Because so few surveyed institutions charged for on-us ATM withdrawals, the increase registered in the level of this fee, from 75 cents in 1997 to 81 cents in 2001, is not statistically significant.

Fees for withdrawals "on others," however, are quite common. By 2001, nearly 80 percent of banks and savings associations charged for withdrawals in which the institution's customer used another institution's ATM. This represents a significant increase of more than 10 percentage points from the 68 percent of institutions that charged this fee in 1997. The average charge also increased significantly over this period, from $\$ 1.05$ in 1997 to $\$ 1.17$ in 2001. This approximately 11 percent increase is equivalent to the increase in the CPI during the period.

More pronounced has been the increase in the incidence of surcharging since 1997, the second year

4. Fees for automated teller machine services - incidence and average level at banks and savings associations, 1997-2001 Dollars except as noted

\begin{tabular}{|c|c|c|c|c|c|c|}
\hline Fee & 1997 & 1998 & 1999 & 2000 & 2001 & $\begin{array}{c}\text { Percent } \\
\text { change, } \\
1997-2001\end{array}$ \\
\hline $\begin{array}{l}\text { Yearly fee } \\
\text { Percentage charging } \\
\text { Fee }\end{array}$ & $\begin{array}{l}14.6 \\
11.15\end{array}$ & $\begin{array}{l}14.2 \\
13.49\end{array}$ & $\begin{array}{c}16.2 \\
7.97\end{array}$ & $\begin{array}{l}13.4 \\
10.76\end{array}$ & $\begin{array}{l}10.7 \\
10.35\end{array}$ & $-7.2^{* * *}$ \\
\hline $\begin{array}{l}\text { Fee for withdrawals "on us" } \\
\text { Percentage charging } \\
\text { Fee }\end{array}$ & $\begin{array}{c}7.4 \\
.75\end{array}$ & $\begin{array}{l}5.7 \\
.71\end{array}$ & $\begin{array}{l}5.6 \\
.58\end{array}$ & $\begin{array}{c}6.3 \\
.69\end{array}$ & $\begin{array}{c}3.6 \\
.81\end{array}$ & $8.0^{k * k}$ \\
\hline $\begin{array}{l}\text { Fee for withdrawals "on others" } \\
\text { Percentage charging } \\
\text { Fee }\end{array}$ & $\begin{array}{c}68.0 \\
1.05\end{array}$ & $\begin{array}{c}77.3 \\
1.10\end{array}$ & $\begin{array}{c}72.0 \\
1.17\end{array}$ & $\begin{array}{c}72.7 \\
1.16\end{array}$ & $\begin{array}{c}78.5 \\
1.17\end{array}$ & $11.4 * * *$ \\
\hline $\begin{array}{l}\text { Surcharge } 1 \\
\text { Percentage charging } \\
\text { Fee }\end{array}$ & $\begin{array}{c}56.2 \\
1.11\end{array}$ & $\begin{array}{c}75.7 \\
1.20\end{array}$ & $\begin{array}{c}81.5 \\
1.25\end{array}$ & $\begin{array}{c}75.3 \\
1.25\end{array}$ & $\begin{array}{c}88.5 \\
1.32\end{array}$ & $18.9 * *$ \\
\hline
\end{tabular}

NoTE. For transactions "on us," the machine used is that of the customer's institution. See also general note to table 1.

1. Fee levied by ATM owners on users who do not maintain an account with the depository institution operating the ATM. Survey of this charge began in 1996.

Percent change for "percentage offering" not reported, but instances of statistically significant change are noted.

* Significant at the 90 percent confidence level.

** Significant at the 95 percent confidence level.

n.a. Not available 
that data were collected on this fee. The proportion of banks and savings associations charging nondepositors a surcharge for use of their ATMs increased significantly, from about 56 percent in 1997 to more than 88 percent in 2001. In 1996 (not shown in table 4 ), the proportion was only 45 percent. $^{6}$

Estimates of the average surcharge levied by the institutions that imposed the fee also increased significantly over the 1997-2001 period, to $\$ 1.32$ per transaction in 2001. This 19 percent increase substantially exceeded the increase in the CPI during the period.

\section{COMPARISONS BETWEEN، LARGE AND SMALL INSTITUTIONS}

Under the terms of the 1994 Riegle-Neal legislation, the Board's annual reports have included separate analyses of fees and services by size class of institution. Beginning with the 1995 report, results for banks and savings associations were reported for three asset-size classes. The reports showed changes

6. Before 1996, the operating rules of the Cirrus and Plus national ATM networks prohibited owners of ATMs linked to those networks from imposing surcharges in most states. These networks eliminated this surcharge ban as of April 1, 1996, and the incidence of surcharging began to increase shortly thereafter. from year to year by size class of institution, but they did not compare directly the level of fees and availability of services across size classes in each year. For this article, such a comparison has been made using the 2001 data for seven common accounts, services, and actions (table 5). The results are reported for large institutions (assets of more than $\$ 1$ billion), medium-sized institutions ( $\$ 100$ million to $\$ 1$ billion), and small institutions (less than $\$ 100$ million).

In 2001, for all but one fee, that for deposit items returned, the average level rose with the asset size of the institution (table 5). With the exception of the charge for deposit items returned, the registered differences in the fees charged by large and small institutions are statistically significant. Further, in the case of the common type of NOW account reported, the minimum balance to avoid a fee at large institutions was significantly higher than at small institutions. And in the case of special actions and ATM services, the proportions of institutions charging a fee were also significantly higher at large than at small banks (except in the case of stop-payment orders and NSF checks, for which virtually all institutions charge).

It is possible that large institutions charge higher fees because they tend to operate in urban areas that may entail higher costs or have some other characteristic that results in higher fees. Therefore, the possibility exists that, after statistically controlling for the

5. Fees for selected accounts, services, and special actions, by asset-size class of bank, 2001

Dollars except as noted

\begin{tabular}{|c|c|c|c|c|}
\hline Item & $\begin{array}{c}\text { Small } \\
(1)\end{array}$ & $\begin{array}{l}\text { Medium } \\
\text { (2) }\end{array}$ & $\begin{array}{c}\text { Large } \\
\text { (3) }\end{array}$ & $\begin{array}{l}\text { Difference } \\
(3-1)\end{array}$ \\
\hline $\begin{array}{l}\text { Singfe tudomese and fee actonm } \\
\text { Noninterest checking } \\
\text { Monthly low-balance fee } . . . . . . \\
\text { Minimum balance to avoid fee }\end{array}$ & $\begin{array}{r}6.59 \\
511.46\end{array}$ & $\begin{array}{r}7.58 \\
537.72\end{array}$ & $\begin{array}{r}8.64 \\
580.11\end{array}$ & $\begin{array}{l}2.05^{* * *} \\
68.65\end{array}$ \\
\hline $\begin{array}{l}\text { NOW account } \\
\text { Monthly low-balance fee } \\
\text { Minimum balance to avoid fee }\end{array}$ & $\begin{array}{r}7.61 \\
981.87\end{array}$ & $\begin{array}{r}8.52 \\
1,180.11\end{array}$ & $\begin{array}{r}10.71 \\
2,122.53\end{array}$ & $\begin{array}{r}3.10^{* * *} \\
1,140.66^{* * *}\end{array}$ \\
\hline $\begin{array}{l}\text { Special actions } \\
\text { Stop-payment orders } \\
\text { Percentage charging } \ldots . . \\
\text { Average fee } \ldots . . . . . \ldots \ldots\end{array}$ & $\begin{array}{l}98.8 \\
16.69\end{array}$ & $\begin{array}{l}99.6 \\
19.46\end{array}$ & $\begin{array}{c}100.0 \\
21.53\end{array}$ & $\begin{array}{l}1.2 \\
4.84 * *\end{array}$ \\
\hline $\begin{array}{l}\text { NSF checks } \\
\text { Percentage charging } \\
\text { Average fee } \ldots . . . . .\end{array}$ & $\begin{array}{c}100.0 \\
19.33\end{array}$ & $\begin{array}{c}100.0 \\
22.05\end{array}$ & $\begin{array}{c}100.0 \\
24.70\end{array}$ & $\begin{array}{c}0 \\
5.37^{* * * *}\end{array}$ \\
\hline $\begin{array}{l}\text { Deposit items returned } \\
\text { Percentage charging } \\
\text { Average fee } . . . . . . . .\end{array}$ & $\begin{array}{c}64.9 \\
6.82\end{array}$ & $\begin{array}{l}83.4 \\
7.60\end{array}$ & $\begin{array}{c}96.6 \\
5.90\end{array}$ & $\begin{array}{c}31.7 * * \\
-.92\end{array}$ \\
\hline $\begin{array}{l}\text { ATM services } \\
\text { Withdrawals on others } \\
\text { Percentage charging } \\
\text { Average fee ......... }\end{array}$ & $\begin{array}{c}74.5 \\
1.11\end{array}$ & $\begin{array}{l}81.5 \\
1.19\end{array}$ & $\begin{array}{l}93.0 \\
1.39\end{array}$ & $\begin{array}{l}18.5^{* * * *} \\
.28 * *\end{array}$ \\
\hline $\begin{array}{l}\text { Surcharge } \\
\text { Percentage charging } \\
\text { Average fee .......... }\end{array}$ & $\begin{array}{l}84.5 \\
1.28\end{array}$ & $\begin{array}{l}92.0 \\
1.34\end{array}$ & $\begin{array}{l}97.9 \\
1.44\end{array}$ & $\begin{array}{r}13.4 * * \\
.16 * *\end{array}$ \\
\hline
\end{tabular}

Note. Small banks are those with assets of less than $\$ 100$ million; large banks are those with assets of more than $\$ 1$ billion. See also general notes to tables 1,3 , and 4 .

**: Significant at the 95 percent confidence level. 
6. Amount by which fees for selected services and special actions at large institutions are higher (lower, -) than those at small institutions after controlling for location ofi institution, 2001

Dollars

\begin{tabular}{|c|c|}
\hline Item & Difference \\
\hline $\begin{array}{l}\text { Single balance and fee account } \\
\text { Monthly low-balance fee } \\
\text { Noninterest checking } \\
\text { NOW account }\end{array}$ & $\begin{array}{l}1.93^{*} \\
2.83^{* *}\end{array}$ \\
\hline $\begin{array}{l}\text { Special actions } \\
\text { Stop-payment orders } \ldots \ldots \ldots \\
\text { NSF checks } \ldots \ldots \ldots \ldots \\
\text { Deposit items returned }\end{array}$ & $\begin{array}{l}4.69^{* * *} \\
4.06^{* * *} \\
-.93\end{array}$ \\
\hline $\begin{array}{l}\text { ATM services } \\
\text { ATM withdrawals "on others" } \\
\text { Surcharge } \ldots \ldots \ldots \ldots \ldots \ldots \ldots\end{array}$ & $\begin{array}{l}.25^{\text {*** }} \\
.12\end{array}$ \\
\hline
\end{tabular}

* Significant at the 90 percent confidence level.

** Significant at the 95 percent confidence level.

influence of location on fees, the observed differences between the fees of large and small institutions would decline substantially or even disappear.

Through a statistical procedure (multivariate regression analysis), the fees of large, medium-sized, and small institutions were compared after controlling for the general location of the institution, as indicated by the state or consolidated metropolitan statistical area in which the institution is located. The estimated differences in fees between large and small institutions were then found to have declined somewhat, and the observed difference in the level of the surcharge was no longer statistically significant. But in most cases, estimated differences, although somewhat smaller, remained substantial and statistically significant (table 6).

The reasons for the remaining differences in fees between larger and smaller institutions may be speculated upon but are difficult to determine. One possibility is that a number of larger organizations tend to depend less on retail customers for funds than smaller institutions do because they may obtain funds from other sources more cheaply; therefore large institutions on average may be relatively less inclined to hold down retail fees for the purpose of attracting the retail customer. Another possibility concerns the services provided by larger organizations; perhaps they are of better quality or are more varied than those provided by smaller institutions and thus warrant the higher charge to the customer. And, finally, locational differences may fully account for the fee differences between larger and smaller organizations, but the data available do not permit the level of detail necessary for an analysis to settle this question, let alone to explore the questions regarding possible differences in service quality and sources of funds.

\section{SUMMARY}

Analysis of the data from the Board's annual surveys of retail fees charged by depository institutions for the most recent five years (1997-2001) shows that for the most common types of depository accounts surveyed, monthly fees tended to rise by statistically significant amounts, as did the minimum balances that depositors must maintain to avoid the fees. Survey results reveal a more mixed picture for the average minimum balances required to open an account.

The fees associated with special actions, such as stop-payment orders and checks returned for insufficient funds, rose significantly and by substantially more than the rate of consumer price inflation over the period. While the proportion of institutions charging some types of ATM fees declined over the period, the incidence and level of the more common types of ATM fees increased significantly. In particular, the proportion of institutions charging the so-called surcharge rose dramatically, and the level of the fee rose significantly and by an amount that substantially exceeded the rate of inflation.

Finally, this article used the data obtained from the 2001 survey on fees charged for seven common services and special actions to compare the fees charged by large institutions with those of small institutions. For all but one of the items, large banks and savings associations (assets of more than $\$ 1$ billion) charged significantly more than small institutions (assets of less than $\$ 100$ million). After an analysis that controlled for the general location of the institution, the differences narrowed somewhat but in most cases remained statistically significant.

\section{APPENDIX: DESIGN. OF THE SURVEYS}

The data employed in this article were obtained through telephone interviews conducted by Moebs Services, of Lake Bluff, Illinois, under contract with the Board of Governors of the Federal Reserve System. The number of institutions surveyed varied over the 1997-2001 period, with about 1,040 surveyed in 1997 and approximately 630 surveyed in 2001.

The statistical design of the survey consists of a stratified random sample, with seven geographic regions and three size classifications serving as the strata. Because selection probabilities differ by region and size class, the inverses of the selection probabilities were employed as weights. These weights were then employed to obtain the population estimates.

A number of changes in the statistical design were made over this period. As explained in the text, the 
most important of these was the combining of banks and savings associations in the calculation and reporting of fee estimates. The number of size classifications serving to define the strata was also reduced from five to three during this period. To facilitate comparisons of fee estimates over time, estimates originally reported for 1997 and 1998 were recalculated using weights based on these changes. 